\title{
List of Maps and Illustrations
}

Fig. 1.0 World Map in Mercator's Projection with Distinctive Features and Ocean Currents [Erdkarte in Mercators Projection mit Bezeichnung der Meeresstromungen], 1867, Heinrich Kiepert. Courtesy of David Rumsey Map Collection, www.davidrumsey.com - 10

Fig. 1.1 Orientalist Congress’ Party at Bygdøy, Kristiania (Oslo), September 9, 1889, with Oscarshall in the background, by Olaf Krohn. ( $)$ Oslo Museum. Photo: Rune Aakvik — 12

Fig. 1.2 Conrad Schick's model of the Haram al-Sharif/Temple Mount. Ordered by the Ottoman authorities for display at the Ottoman Pavilion, World Exhibit Vienna, 1873. Current location: Christ Church, Jerusalem. Photo: Ulf Petersson - 20

Fig. 1.3 Another of Conrad Schick's models: Herod's Temple, 1898-1916. American Colony Photo-Department photographers. Photographic print, hand-drawing. Sven Hedin Foundation, Etnografiska Museet, Stockholm - 21

Fig. 1.4 Panoramic View of Jerusalem, 1900-1920. Hand-tinted photographic print. American Colony Photo-Department photographers. Boaz Collection of Israeli Photography, Jerusalem - 32

Fig. 2.0 Adolph Tidemand, Haugianerne [Low Church Devotion], 1848. Oil on canvas, $98,8 \times 123,3 \mathrm{~cm}$. ( $)$ The National Museum of Art, Architecture and Design, Oslo. Foto: Jacques Lathion. CC-BY-NC $-\mathbf{5 2}$

Fig. 2.1 The Main Building of the Waisenhaus in Halle, 1749. Engraving by Gottfried August Gründler. Public Domain — 56

Fig. 3.1 Interior of Swedenborgs Minneskyrka, Stockholm. Courtesy of Swedenborgs Minneskyrka. Photo: Thomas Xavier Floyd, $2015-74$

Fig. 3.2 Emanuel Swedenborg, Spiritual Diary Vol. 3. (RSAS MS Swedenborg 128:3, Cod. 3B). Courtesy of the Royal Swedish Academy of Sciences. Photo: Devin Zuber - $\mathbf{8 1}$

Fig. 3.3 New Jerusalem, Sanctuary Mural, Erik Stenholm, Swedenborgs Minneskyrka. Courtesy of Swedenborgs Minneskyrka. Photo: Thomas Xavier Floyd, 2015 - 84

Fig. 4.1 "Du ewiger Abgrund der Seeligen Liebe in Jesu Christo aufgethan Hebr 12:1.2." Frontispiece of Christian David's Beschreibung und Zuverläßige Nachricht von Herrnhut (Leipzig, 1735). Copper engraving -86

Fig. 4.2 A choir speech with pages held together by a sewing pin, from S.A.I.R.5.a. Korreden and S.A.I.R.5.b. Korreden, Moravian archive, Christiansfeld -96

Fig. 4.3 Christmas Celebration at the Moravian Boarding School for Girls in Bethlehem, Pennsylvania, c.1800, by Anna Rosina Klies. Watercolour on paper. Moravian Archives, Kliest Collection - 102

Fig. 5.1 The new Herrnhut mission in Greenland, c.1770. From Heinz Barüske, Grönland: Kultur und Landschaft am Polarkreis, 1990. Public domain. Wikimedia Commons. - 110

Fig. 6.1 Christiansfeld, 1780, by Meno Haas. Copper engraving. Royal Danish Library - 118

Fig. 6.2 Survey map of Christiansfeld with coloured timeline of erected houses, 1940s. The town plan is still the same today. Royal Danish Library - Danish National Art Library - 120

Fig. 6.3 Early survey by Staunager from 1812 where quadrates measured in Ruthen are indicated. Brødremenigheden, The Moravian Church in Christiansfeld — 124 
Fig. 7.1 Dram (Drammen), c.1800, by John William Edy. From Boydell's picturesque scenery of Norway, 1820, plate no. 71. Courtesy of the National Library of Norway. Public domain 129

Fig. 8.1 Hans Nielsen Hauge, bronze bust by Thorsten Christensen Flatmoe (1831-1886). Østfold fylkes billedarkiv. Photo: Kjell Bertheau Johannessen.

CC BY-NC-ND - 138

Fig. 8.2 Hymn entitled The New Jerusalem, Revelations 21 by an anonymous adherent of the Haugean movement. Heggtveitsamlingen, MF The Norwegian School of Theology, Religion and Society Archive. Photo: Kristin B. Aavitsland - 154

Fig. 9.1 Ekerhovd Prayer House, Hordaland, Norway. Photo: Johann Vannes, $2018-164$

Fig. 9.2 Interior, Ekerhovd Prayer House, Hordaland, Norway. Photo: Johann Vannes, 2018. The shields with bible verses are quite old but not original. The painting is of a more recent date $-\mathbf{1 8 0}$

Fig. 10.1 Christmas card with the inscription "Restaurationen with the first Norwegian emigrants leaves Stavanger [in Norway] in the year 1825." Public domain - 202

Fig. 11.0 Christ, c.1821/39, by Bertel Thorvaldsen. The Church of Our Lady, Copenhagen. (C) The National Museum of Denmark, Copenhagen. Photo: Arnold Mikkelsen, 2018. CC-BY-SA — 212

Fig. 11.1 Portrait of N.F.S. Grundtvig. Reproduced by courtesy of www.skolehistorie.au. dk. () AU Library, Campus Emdrup (DPB) - 214

Fig. 12.1 J. L. Lund, Christ Blessing, 1831. Søllerød Church. The National Museum of Denmark, Copenhagen. Photo: Arnold Mikkelsen, 2018. CC-BY-SA — 224

Fig. 12.2 Heinrich Eddelien, Christ Blessing, 1846. Ishøj Church. The National Museum of Denmark, Copenhagen. Photo: Arnold Mikkelsen, 2018. CC-BY-SA — 232

Fig. 12.3 Heinrich Eddelien, Christ Blessing the Children, 1843. Maarum Church. The National Museum of Denmark, Copenhagen. Photo: Arnold Mikkelsen, 2018. CC-BY-SA -233

Fig. 12.4 C. W. Eckersberg, Christ and the Samaritan Woman, 1838. Hornbæk Church. The National Museum of Denmark, Copenhagen. Photo: Arnold Mikkelsen, 2018. CC-BY-SA 235

Fig. 12.5 Constantin Hansen, Christ in the House of Martha and Mary, 1846. Valby Church. The National Museum of Denmark, Copenhagen. Photo: Arnold Mikkelsen, 2018. CC-BY-SA $2 \mathbf{2 3 8}$

Fig. 12.6 C. W. Eckersberg, The Greatest in the Kingdom of Heaven, 1842. St. Nicholas' Church, Middelfart. The National Museum of Denmark, Copenhagen. Photo: Arnold Mikkelsen, 2009. CC-BY-SA — 240

Fig. 12.7 C. W. Eckersberg, The Incredulity of Thomas, 1833. Skævinge Church. The National Museum of Denmark, Copenhagen. Photo: Arnold Mikkelsen, 2018. CC-BY-SA 2241

Fig. 13.1 Skibby Church, Zealand, Denmark. Exterior. H. B. Storck, 1860. Pencil and water colour, $17 \times 25 \mathrm{~cm}$. The National Museum of Denmark. Public domain - 244

Fig. 13.2 Endelave Church, Jutland, Denmark. Interior facing East. Before 1890. The National Museum of Denmark. CC-BY-SA $2 \mathbf{2 4 8}$

Fig. 13.3 Married to an Old Maid (plate 5) from A Rake's Progress, 1735, by William Hogarth. Engraving. Public domain, Wikimedia Commons -252

Fig. 13.4 Church of Our Lady, Copenhagen. Interior facing East, 1840-1849. Engraving. The Royal Library, Copenhagen. Public domain - 256 
Fig. 13.5 The Old Uldum Church, Jutland, Denmark. Elevation, North, 1:300, 1881. Drawing and measurements by Tage Olivarius. The National Museum of Denmark. CC-BY-SA 261

Fig. 13.6 The New Uldum Church, Jutland, Denmark. South-West, c.1900. The National Museum of Denmark. CC-BY-SA — 261

Fig. 13.7 The New Uldum Church, Jutland, Denmark. Interior facing East, c.1900. The National Museum of Denmark. CC-BY-SA -262

Fig. 14.1 Sanctus Summum, by Johann Georg Herzog, printed in Siona, $1879-267$

Fig. 15.0 Fredrika Bremer's travel map over Palestine and Egypt. The National Library of Sweden, Stockholm. Photo: Ann-Sofie Persson - 278

Fig. 15.1 Map of Jerusalem (undated) by Catharine Hermine Kølle. Photo: Svein Skare $\odot$ University Museum of Bergen. CC BY-SA 4.0 280

Fig. 15.2 Detail of Kølle's Jerusalem map (Fig. 15.1) -287

Fig. 15.3 Vera Hierosolymae Veteris Imago. An imaginary plan drawn after Villalpando. From Eusebius, Kanaän en d'omleggende landen . . . Leeuwarden, François Halma, 1717. Copperplate. The National Library of Israel, The Eran Laor Cartographic Collection. Public domain - 291

Fig. 15.4 Urbs Hierosolyma ex Descriptione Joan Lightfootii, from John Lightfoot's Opera omnia . . . (Francecker, Leonard Strik, 1699). Copperplate. The National Library of Israel, The Eran Laor Cartographic Collection. Public domain - 292

Fig. 15.5 Christiansfeld, c.1826-1827, by Catharine Hermine Kølle. Signed C.K. Photo: Svein Skare (C) University Museum of Bergen. CC BY-SA 4.0 298

Fig. 15.6 The Baptism of Christ, undated and untitled, by Cathrine Hermine Kølle. Lokalhistorisk arkiv, Ulvik herad. Photo: Knut Aslaksen @ University Museum of Bergen. CC BY-SA $4.0-304$

Fig. 16.1 Scene of the Return of the Ark - Wady Sŭrâr, from William M. Thomson's The Land and the Book, or, Biblical Illustrations Drawn from the Manners and Customs, the Scenes and Scenery, of the Holy Land, 1880 - 316

Fig. 16.2 Map of Jerusalem, in Edward Robinson's Biblical Researches in Palestine, and in the Adjacent Regions. A Journal of Travels in the Year 1838, 1856 - 322

Fig. 17.1 Flowers from Bethany, from Wild Flowers of the Holy Land, pressed flower album, late nineteenth century. Created by Ferdinand Ludwig Vester, Jerusalem; printed by Joseph Schor. Ami Zehavi Collection of Pressed Flowers of the Holy Land, Tel-Aviv. On permanent loan at the American Colony Archive, Jerusalem $-\mathbf{3 2 8}$

Fig. 17.2 Anna T. Spafford in American Colony Courtyard, c.1898-1923. Hand-tinted photographic print. Hol Lars (Lewis) Larsson, the American Colony PhotoDepartment - 337

Fig. 17.3 Plants collected by Fredrika Bremer. The Bremer Collection at Årsta Castle, Årstasällskapet för Fredrika Bremer-studier (The Årsta Association for Fredrika Bremer Studies). Photo: Lina Stenqvist - $\mathbf{3 4 2}$

Fig. 18.1 Fredrika Bremer photographed by C. J. Malmberg in 1862 upon return from her journey to Southern Europe and Palestine. By courtesy of Årstasällskapet för Fredrika Bremer-studier [The Årsta Association for Fredrika Bremer Studies] - 360

Fig. 18.2 Fredrika Bremer's travel cutlery. The Bremer Collection at Årsta slott, Årstasällskapet för Fredrika Bremer-studier [The Årsta Association for Fredrika Bremer Studies]. Photo by Lina Stenqvist - 364

Fig. 18.3 Map of Jerusalem drawn by H. Lange in Carl Ritter's Die Erdkunde vol. XVI, 1852. By courtesy of Stockholm University Library. Photo: Torsten Håkansson - 368 
Fig. 18.4 Carl Jonas Love Almqvist, painting attributed to Johan Gustaf Köhler, date unknown. The National Museum of Fine Arts, Stockholm. Photo: Erik Cornelius, 2007. Public domain - 378

Fig. 18.5 The Pilgrim's Progress or Christians journey from the City of Destruction in this evil World to the Celestial City in the World that is to Come, 1813. Published by J. Pitts, London. Hand-coloured etching. () Trustees of the British Museum. CC BY-NC-SA $4.0-381$

Fig. 19.1 Map over The Lands of the Bible, in Hans Julius Knudsen, Bibelsk Geographie for Skoler og Familier, $1858-390$

Fig. 19.2 Map of Canaan, in Volrath Vogt, Bibelsoga med noko av kyrkesoga, 1900 - 395

Fig. 19.3 The Wandering of the Israelites, in Volrath Vogt, Bibelhistorie for folkeskolen, $1931-397$

Fig. 19.4 The Wandering in the Desert, illustration by Kathrine Kleveland, in Volrath Vogt, Bibelhistorie, 1993 - 398

Fig. 19.5 Map of Palestine, illustration by Lars Wangensteen Berge, in Anna Amundsen, Jeg så ham som barn - Bibelhistorie for folkeskolen, $1954-400$

Fig. 19.6 Den forsvunne diamant (detail), Norwegian edition of the Finnish board game Afrikan tähti. By courtesy of Egmont Kids Media, Norway. All rights reserved to the rights holders of Kari Mannerla - 401

Fig. 19.7 Map from Aschehoug's School Atlas, by Ivar Refsdal, $1964-403$

Fig. 19.8 "Aschehoug's Map of Palestine in the Age of Christ," classroom map, mid-twentieth century. Constructed and drawn by B. Luncke and Scott-Ruud. Courtesy of Aschehoug \& Co., Oslo. Photo: Are Flågan, National Library of Norway, Oslo -405

Fig. 19.9 With Moses from Egypt to Israel, illustration by Kjersti Scheen, in Jeg kan: Kristendomskunnskap for grunnskolen 2. Arbeidsbok, by Bjørn Gjefsen, Randi Dyrerud, and Helene Dæhlin, 1993 - 406

Fig. 19.10 Socrates and the Brain Labyrinth, illustration by Hilde Hodnefjeld, in Under Treet: Kristendomskunnskap med religions-og livssynsorientering for 2. klasse: Arbeidsbok, by Bjørn Gjefsen, Helene Dæhlin, and Elen Egeland, $1997-407$

Fig. 19.11 Josef and Mary on their Way to Bethlehem, illustration by Hilde Hodnefjeld, in Under Treet: Kristendomskunnskap med religions- og livssynsorientering for 2. klasse: Arbeidsbok, by Bjørn Gjefsen, Helene Dæhlin, and Elen Egeland, $1997-407$

Fig. 20.1 Interior, Mosque of Omar, from Volrath Vogt, Det Hellige Land, $1879-410$

Fig. 20.2 Jerusalem. Illustration from Birger Hall's Fra Østen. Reiseerindringer fra Agypten, Syrien og Palæstina, $1888-421$

Fig. 21.1 Nazareth, plate 9, in Paul Peter Waldenström's Till Österland. Photo: Magnus Bremmer -430

Fig. 21.2 Jerusalem, From the Mount of Olives, Looking Over the Valley of Jehoshaphat, c.1865, by Francis Frith. The J. Paul Getty Museum, Los Angeles - 437

Fig. 21.3 The Valley of Hinnom, plate 13, in Paul Peter Waldenström's Till Österland. Photo: Magnus Bremmer -438

Fig. 21.4 The Church of the Nativity in Bethlehem, plate 16, in Paul Peter Waldenström's Till Österland. Xylographic reproduction by Wilhelm Meyer. Photo: Magnus Bremmer $-\mathbf{4} 40$

Fig. 21.5 The Church of the Holy Sepulchre, in Paul Peter Waldenström's Till Österland, page 392-3. Photo: Magnus Bremmer -442 
Fig. 22.0 Gerhard Munthe: Sigurd and Baldwin, 1899. Tempera, $143 \times 103 \mathrm{~cm}$. (C) Trondheim kunstmuseum. Photo: Ute Freia Beer — 446

Fig. 22.1 Selma Lagerlöf painted in her home in Falun by Carl Larsson in 1908. Bonniers Porträttsamling, Stockholm — 448

Fig. 22.2 Postcard from Jerusalem sent by Selma Lagerlöf to her mother on March 4, 1900. Courtesy of Lena Carlsson and Anneli Oxenstierna. Photo: Anneli Oxenstierna -452

Fig. 22.3 Dalmålning [Dalarna Painting] by Snarf Anders Andersson. Inscribed "Christus Gråter ofwer staden Jerusalem 1819 A. A. S [Christ Crying over the City of Jerusalem 1819].” Nordiska museet, Stockholm. Photo: Sören Hallgren — 454

Fig. 23.1 Norwegian immigrants harvesting in Wisconsin, c.1873-1879. (C) State Historical Society of Wisconsnin - Andrew Dahl Collection. Photo: Andreas Larsen Dahl 466

Fig. 23.2 Siri Rustebakke with her daughters and daughter-in-law. Wisconsin, c.1873. (C) State Historical Society of Wisconsin - Andrew Dahl Collection. Photo: Andreas Larsen Dahl $\mathbf{4 7 0}$

Fig. 23.3 Harvest, American Colony, 1904. American Colony Photo Department. Library of Congress, Prints and Photographs Division, Washington, D.C -487

Fig. 23.4 The Weaving Room in the American Colony, Jerusalem, 1904. American Colony Photo Department. Library of Congress, Prints and Photographs Division, Washington D. C— 488

Fig. 24.1 Augusta Victoria Stiftung on Olivet, 1910-1914. Hol Lars (Lewis) Larsson, American Colony Photo-Dept. Photographic print, hand-tinted. Sven Hedin Foundation, Etnografiska Museet, Stockholm — 492

Fig. 24.2 Hol Lars (Lewis) Larsson, photographing in Tibne, Jordan, 1910. American Colony Photo-Dept. photographers. Glass lantern slide. Uppsala University Library Collection - $\mathbf{4 9 7}$

Fig. 24.3 David Street, Jerusalem, 1900-1916. American Colony Photo-Dept. photographers. Photographic print, hand-tinted. Sven Hedin Foundation, Etnografiska Museet, Stockholm $\mathbf{5 0 7}$

Fig. 24.4 Al-Aqsa Mosque, 1900-1916. Hol Lars (Lewis) Larsson, American Colony PhotoDept. Photographic print, hand-tinted. Sven Hedin Foundation, Etnografiska Museet, Stockholm $\mathbf{5 0 8}$

Fig. 24.5 Jerusalem's Locust Plague: Colony Members Fighting the Locust, 1915. Hol Lars (Lewis) Larsson, American Colony Photo-Dept. Photographic print, hand-tinted. Sven Hedin Foundation, Etnografiska Museet, Stockholm $\mathbf{5 0 9}$

Fig. 25.1 Hilma Granqvist in local costume together with two children. (C) Palestine Exploration Fund. PEF-P-GRAN-M1-10 (KS Frontispiece) - $\mathbf{5 1 2}$

Fig. 26.1 The Soup Kitchen “Green Hall," Signe Ekblad, children and mothers, 1939. Copyright: Uppsala University Library, Uppsala - $\mathbf{5 1 8}$

Fig. 26.2 Signe Ekblad and children by The Swedish School's foundation stone, March, 1928. Copy right: Uppsala University Library, Uppsala - $\mathbf{5 3 5}$

Fig. 26.3 The Swedish School in Jerusalem. Copyright: Uppsala University Library, Uppsala - 536

Fig. 26.4 Physical education outdoors, c.1930. The Swedish Jerusalem Society’s School. Copyright: Uppsala University Library, Uppsala — $\mathbf{5 3 8}$

Fig. 27.1 The Nordic Cross Flags. Photo: Jan Rietz/pixgallery.com - $\mathbf{5 4 0}$ 
Fig. 28.1 Sigurd and Baldwin, 1900. Tapestry made by The Norwegian Tapestry Weaving Company/Det norske Billedvæveri. 456 x $340 \mathrm{~cm}$. The Royal Palace, Oslo. Photo: Kjartan Hauglid, De kongelige samlinger - $\mathbf{5 5 0}$

Fig. 28.2 The Entry into Miklagard, 1900. Tapestry made by The Norwegian Tapestry Weaving Company/Det norske Billedvæveri. 452 x $336 \mathrm{~cm}$. The Royal Palace, Oslo. Photo: Kjartan Hauglid, De kongelige samlinger - $\mathbf{5 5 2}$

Fig. 28.3 The National Tapestries displayed in the main staircase of The Royal Palace, Oslo. Photo: Severin Worm-Petersen: Det Kongelige Slott. The Norwegian Museum of Science and Technology $-\mathbf{5 5 3}$

Fig. 28.4 Gerhard Munthe: King Sigurd and King Baldwin Riding from Jerusalem to the Jordan River. Illustration from Snorri Sturluson, Heimskringla, $1899-554$

Fig. 28.5 Gerhard Munthe: The Entry into Miklagard. Illustration from Snorri Sturluson, Heimskringla, $1899-\mathbf{5 5 5}$

Fig. 28.6 Gerhard Munthe: The Entry into Myklagard, 1899. Tempera, $143 \times 103 \mathrm{~cm}$. (C) Trondheim kunstmuseum. Photo: Ute Freia Beer — 557

Fig. 28.7 Gerhard Munthe: Sigurd and Baldwin. (Detail, Fig. 22.0) - 558

Fig. 28.8 Gerhard Munthe: The Entry into Miklagard. (Detail, Fig. 28.6) - 558

Fig. 28.9 Friedrich Perlberg: View of Jerusalem, c.1898. Water colour on paper. Private Collection / Photo (c) Christie's Images / Bridgeman Images — $\mathbf{5 6 2}$

Fig. 28.10 Frida Hansen: The Dance of Salomé, 1900.193 x $682 \mathrm{~cm}$. Museum für Gestaltung Zürich — $\mathbf{5 7 3}$ 